\title{
Cophylogenetic interactions between marine viruses and eukaryotic picophytoplankton
}

\author{
Laure Bellec ${ }^{1,2}$, Camille Clerissi ${ }^{1,2}$, Roseline Edern ${ }^{3,4}$, Elodie Foulon ${ }^{3,4}$, Nathalie Simon ${ }^{3,4}$, Nigel Grimsley ${ }^{1,2}$ \\ and Yves Desdevises ${ }^{1,2^{*}}$
}

\begin{abstract}
Background: Numerous studies have investigated cospeciation (or cophylogeny) in various host-symbiont systems, and different patterns were inferred, from strict cospeciation where symbiont phylogeny mirrors host phylogeny, to complete absence of correspondence between trees. The degree of cospeciation is generally linked to the level of host specificity in the symbiont species and the opportunity they have to switch hosts. In this study, we investigated cophylogeny for the first time in a microalgae-virus association in the open sea, where symbionts are believed to be highly host-specific but have wide opportunities to switch hosts. We studied prasinovirus-Mamiellales associations using 51 different viral strains infecting 22 host strains, selected from the characterisation and experimental testing of the specificities of 313 virus strains on 26 host strains.
\end{abstract}

Results: All virus strains were restricted to their host genus, and most were species-specific, but some of them were able to infect different host species within a genus. Phylogenetic trees were reconstructed for viruses and their hosts, and their congruence was assessed based on these trees and the specificity data using different cophylogenetic methods, a topology-based approach, Jane, and a global congruence method, ParaFit. We found significant congruence between virus and host trees, but with a putatively complex evolutionary history.

Conclusions: Mechanisms other than true cospeciation, such as host-switching, might explain a part of the data. It has been observed in a previous study on the same taxa that the genomic divergence between host pairs is larger than between their viruses. It implies that if cospeciation predominates in this algae-virus system, this would support the hypothesis that prasinoviruses evolve more slowly than their microalgal hosts, whereas host switching would imply that these viruses speciated more recently than the divergence of their host genera.

Keywords: Cophylogeny, Prasinovirus, Phycodnaviridae, Mamiellale, Chlorophyta, Specificity

\section{Background}

Viruses are recognized as important players in marine microbial ecosystems [1], but while the role of prokaryotic viruses (phages) has been widely appreciated in the last decades [2], our knowledge about viruses infecting the eukaryotic microbes and in particular microalgae, is much more recent [3,4]. Algal viruses, like aquatic phages, regulate the ecology and the evolution of their host populations via lysis and horizontal gene transfer

\footnotetext{
* Correspondence: desdevises@obs-banyuls.fr

${ }^{1}$ Integrative Biology of Marine Organisms, Observatoire Océanologique, Sorbonne Universités, UPMC Univ Paris 06, UMR 7232, F-66650

Banyuls-sur-Mer, France

${ }^{2}$ Integrative Biology of Marine Organisms, Observatoire Océanologique,

CNRS, UMR 7232, 66650 Banyuls-sur-Mer, France

Full list of author information is available at the end of the article
}

[5], but they show high levels of host specificities [6-8]. In order to gain some understanding of oceanic ecosystems, it is thus important to analyse how viruses are transmitted from a host to another: are they mostly vertically transmitted, from ancestor to descendant, hence globally coevolving and cospeciating with their hosts with limited possibilities to switch to other host species, or can they easily colonize different host species, even phylogenetically distantly related? An understanding of the pattern of hostvirus cospeciation, or cophylogeny (see $[9,10]$ ) is needed for comparing evolutionary rates based on molecular divergences (e.g. [11]), because it relies on the assumption of simultaneous speciation. Among the best-known viruses of planktonic eukaryotes are the phycodnaviruses (family Phycodnaviridae, [12]). Their similarity in structure (all of them are icosahedral particles enclosing double-stranded 
DNA) combined to the wide diversity of their hosts ("algae" that span most of the eukaryotic evolutionary tree), suggest that host switches have happened in the past. In any case, no detailed study of cophylogenetic interactions (i.e. at a macroevolutionary level) between algal viruses and their hosts has been carried out to date. The present work focuses on the host-virus association formed between prasinophytes, and more precisely, phytoplanktonic genera in the order Mamiellales, and their viruses, the prasinoviruses (see [13]). Mamiellales (class Mamiellophyceae, [14]), are an ecologically important group of marine picoeukaryotes that include three geographically widely distributed genera, Micromonas, Ostreococcus and Bathycoccus [15] (as well as the less represented genera Mamiella, Mantoniella, Dolichomastix and Crustomastix). The genomes of several species in the former three genera and their viruses have been entirely sequenced (see [11]). Numerous genetically diverse strains have been isolated [16-18], and probably encompass more species than those formally described so far (1 Bathycoccus species: B. prasinos Eikrem \& Throndsen 1990, 1 Micromonas species: M. pusilla (Butcher) Manton and Parke 1960, and 3 Ostreococcus species: O. tauri [19], O. lucimarinus [20] and O. mediterraneus [21]). In Micromonas, Guillou et al. distinguished 3 major genetic clades (A, B and C) [16] while other studies [22-24] further distinguished sub-clades within clades A and B depicted in [16] suggesting that this genus contains at least 5 species. In Ostreococcus, Rodriguez et al. [17] have described four distinct clades clustering strains differing in their sensitivities to light (as well as temperature and nutrients [25], and also suggested they represent different species, as recently supported [21]. All of the Bathycoccus strains recorded so far form a more homogeneous evolutionary group [16], but recent work based on metagenomic analyses of natural samples suggested that this genus includes 2 to 3 different genotypes [26]. A similar picture is seen in prasinoviruses of the Mamiellophyceae, which form a monophyletic group [13]. Many genetically different strains have been characterized and form distinct clades according to the host species from which they were isolated [13,27]. Hence, these associations include numerous host and viral strains, but nothing is known to date about their joint macroevolutionary history, that is does the evolution of the viruses follow that of their hosts, which would be reflected by congruent phylogenetic trees?

We hereby investigate the cophylogenetic pattern in this host-virus system using molecular phylogenies, by experimentally assessing the specificity of many virus strains on several host strains, and we use dedicated numerical methods to assess the level of cospeciation. Understanding how hosts and viruses coevolve, taking into account the observed pattern of host specificity, is crucial for predicting the possibility of viral host-switching and for understanding speciation processes. For example, strict host specificity and limited capacities for viruses to switch hosts should be reflected in a strong cospeciation pattern, whereas strict host specificity with no cospeciation suggests a high speciation rate in viruses.

We show that these viruses are generally highly hostspecific and display a significant, while complex, cophylogenetic pattern with their hosts. This may have important implications for the ecology and the dynamics of planktonic ecosystems.

\section{Results}

\section{Specificity}

Experimental tests of host-specificity suggest that virus strains are specific to their host genus (Table 1), and infect in majority host species from the same clade (Table 1 and Figure 1). However, a number of strains display a cross-clade specificity (14 out of 31 (45.2\%) in Micromonas viruses, and 4 out of 18 (22.2\%) in Ostreococcus viruses). Host range (i.e. specificity) varies from 1 to 6 in virus strains studied here, and 18 viruses out of 51 (35.3\%) are strict specialists, infecting only 1 host strain.

The susceptibility of host strains to viruses, i.e. the number of virus strains that can infect a given host strain, varies from 1 to 14 . The most highly susceptible strains are found in Micromonas.

\section{Phylogeny}

Sequences ranged between 609 and 624 bp (DNA polymerase gene or dpo) for viruses and 1996 and 2238 bp (rDNA 18S (1620-1635 bp) + ITS2 (366-607 bp)) for hosts. Respective alignment lengths were 624 bp (208 AA) and 2289 bp. Unpublished sequences were deposited in GenBank (Accession numbers, sequence lengths, strain names, geographical origin, and host culture for isolation are given in Tables 2 and 3 ).

Evolutionary models selected with jModelTest were Tamura-Nei $93+\mathrm{I}+\mathrm{G}$ (accounting for rate heterogeneity across sites via a Gamma distribution with a 0.327 alpha parameter and including $41 \%$ of invariant sites) for hosts (18S + ITS), and CpREV + G + F (using observed AA frequencies, and a 0.78 alpha parameter) for the alignment of virus protein sequences.

Whatever the methods (Bayesian inference (BI) or maximum likelihood (ML)) and datasets (DNA or AA for viruses), phylogenetic trees were the same for hosts and very similar for viruses, therefore only BI trees are presented (Figure 1. These trees and associated alignments were deposited in TreeBASE at the URL http://purl.org/ phylo/treebase/phylows/study/TB2:S15522). The host phylogeny obtained is clearly coherent with the phylogeny of Mamiellophyceae published by [14] where Ostreococcus and Bathycoccus form the Bathycoccaceae and Micromonas strains cluster separately. Three distinct clades are 
Table 1 Host specificity of viruses (Ot stands for Ostreococcus tauri, $\mathrm{Ol}$ is $\mathrm{O}$. lucimarinus, Om is $\mathbf{O}$. mediterraneus, Osp is Ostreococcus sp., and Bp is B. prasinos). - no lysis; $\square$ lysis (isolate from this host); $n$ lysis

\begin{tabular}{|c|c|c|c|c|c|c|c|c|c|c|c|c|c|c|c|c|c|c|c|c|c|c|}
\hline \multirow{2}{*}{$\begin{array}{l}\text { Species } \\
\text { Clade }\end{array}$} & \multicolumn{13}{|c|}{ Micromonas pusilla } & \multirow{2}{*}{$\frac{\mathrm{Ot}}{\mathrm{C}}$} & \multirow{2}{*}{$\frac{\text { Ol }}{A}$} & \multicolumn{3}{|c|}{ Osp. } & \multicolumn{2}{|c|}{ Om } & \multicolumn{2}{|c|}{$\mathrm{Bp}$} \\
\hline & $A$ & $A$ & B & B & B & $B$ & $B$ & C & $C$ & $C$ & $C$ & $C$ & $C$ & & & $A$ & A & C & $D$ & D & & \\
\hline RCC no. & 2485 & 658 & 2482 & 2483 & 418 & 461 & 1109 & 2484 & 834 & 629 & 465 & 373 & 114 & 745 & & 356 & 344 & 1108 & 789 & 1107 & 1105 & 46 \\
\hline MicAV31 & $\square$ & - & - & - & - & - & - & - & - & - & - & - & - & - & - & - & - & - & - & - & - & - \\
\hline MicAV32 & $\square$ & - & - & - & - & & - & - & - & - & - & - & - & - & - & - & - & - & - & - & - & - \\
\hline MicAV27 & $\square$ & - & - & - & - & घ & - & - & - & - & - & - & - & - & - & - & - & - & - & - & - & - \\
\hline MicAV28 & $\square$ & - & - & - & - & - & - & - & - & - & - & - & - & - & - & - & - & - & - & - & - & - \\
\hline MicAV34 & $\square$ & - & - & - & - & घ & - & - & - & - & - & - & - & - & - & - & - & - & - & - & - & - \\
\hline MicAV29 & $\square$ & - & - & - & - & घ & - & - & - & - & - & - & - & - & - & - & - & - & - & - & - & - \\
\hline MicAV30 & $\square$ & - & ! & - & - & - & - & - & - & - & - & - & - & - & - & - & - & - & - & - & - & - \\
\hline MicAV38 & $\square$ & - & - & - & - & - & - & - & - & - & - & - & - & - & - & - & - & - & - & - & - & - \\
\hline MicAV39 & $\square$ & - & ! & - & - & - & - & - & - & - & - & - & - & - & - & - & - & - & - & - & - & - \\
\hline MicBV26 & - & - & $\square$ & ! & - & - & - & - & - & - & - & - & - & - & - & - & - & - & - & - & - & - \\
\hline MicBV16 & ! & - & $\square$ & - & - & - & - & - & - & - & - & - & - & - & - & - & - & - & - & - & - & - \\
\hline MicBV13 & ! & - & $\square$ & ! & - & - & - & - & - & - & - & - & - & - & - & - & - & - & - & - & - & - \\
\hline MicBV40 & ! & - & $\square$ & घ & - & - & - & - & - & - & - & - & - & - & - & - & - & - & - & - & - & - \\
\hline MicBV39 & ! & - & $\square$ & - & - & - & - & - & - & - & - & - & - & - & - & - & - & - & - & - & - & - \\
\hline MicBV25 & - & - & $\square$ & ! & - & & - & - & - & - & - & - & - & - & - & - & - & - & - & - & - & - \\
\hline MicB1 109V4 & - & - & - & - & - & - & $\square$ & - & - & - & - & - & - & - & - & - & - & - & - & - & - & - \\
\hline MicB1109V14 & - & - & - & - & - & - & $\square$ & - & - & - & - & - & - & - & - & - & - & - & - & - & - & - \\
\hline MicB1109V6 & - & - & घ & घ & - & - & $\square$ & - & - & - & - & - & - & - & - & - & - & - & - & - & - & - \\
\hline MicC497V1 & - & - & - & - & - & - & - & $\square$ & - & ! & ! & - & - & - & - & - & - & - & - & - & - & - \\
\hline MicC497V2 & - & - & - & - & - & - & - & $\square$ & - & - & - & - & - & - & - & - & - & - & - & - & - & - \\
\hline MicCV1 & - & - & - & - & - & - & - & - & $\square$ & - & - & & - & - & - & - & - & - & - & - & - & - \\
\hline MicCV36 & - & - & - & - & - & - & - & - & $\square$ & - & - & ! & - & - & - & - & - & - & - & - & - & - \\
\hline MicCV2 & - & - & - & - & - & - & - & - & $\square$ & - & ! & ! & - & - & - & - & - & - & - & - & - & - \\
\hline MicCV21 & - & - & - & - & - & - & - & - & $\square$ & . & - & ! & - & - & - & - & - & - & - & - & - & - \\
\hline MicCV28 & - & - & - & - & - & - & - & - & $\square$ & घ & - & - & - & - & - & - & - & - & - & - & - & - \\
\hline MicCV32 & - & - & - & - & - & - & - & - & $\square$ & घ & ! & ! & - & - & - & - & - & - & - & - & - & - \\
\hline MicCV23 & - & - & - & - & - & - & - & - & $\square$ & ! & ! & & - & - & - & - & - & - & - & - & - & - \\
\hline MicCV22 & - & - & - & - & - & - & - & - & $\square$ & ! & ! & ! & - & - & - & - & - & - & - & - & - & - \\
\hline MicCV3 & - & - & - & - & - & - & - & - & $\square$ & घ & - & - & - & - & - & - & - & - & - & - & - & - \\
\hline MicCV9 & - & - & - & - & - & - & - & - & $\square$ & - & ! & - & - & - & - & - & - & - & - & - & - & - \\
\hline MicCV10 & - & - & - & - & - & - & - & - & $\square$ & ! & ! & ! & - & - & - & - & - & - & - & - & - & - \\
\hline OlV158 & - & - & - & - & - & - & - & - & - & - & - & - & - & - & $\square$ & - & - & - & - & - & - & - \\
\hline Olv349 & - & - & - & - & - & - & - & - & - & - & - & - & - & - & $\square$ & - & - & - & - & - & - & - \\
\hline Olv360 & - & - & - & - & - & - & - & - & - & - & - & - & - & - & $\square$ & - & - & - & - & - & - & - \\
\hline OIV462 & - & - & - & - & - & - & - & - & - & - & - & - & - & - & $\square$ & - & - & - & - & - & - & - \\
\hline OIV536 & - & - & - & - & - & - & - & - & - & - & - & - & - & - & $\square$ & - & - & - & - & - & - & - \\
\hline OtV3 & - & - & - & - & - & - & - & - & - & - & - & - & - & $\square$ & - & - & - & - & - & - & - & - \\
\hline OtV4 & - & - & - & - & - & - & - & - & - & - & - & - & - & $\square$ & - & - & - & - & - & - & - & - \\
\hline OtV9 & - & - & - & - & - & - & - & - & - & - & - & - & - & $\square$ & - & . & - & - & - & - & - & - \\
\hline OtV564 & - & - & - & - & - & - & - & - & - & - & - & - & - & $\square$ & ! & - & - & - & ! & - & - & - \\
\hline OtV565 & - & - & - & - & - & - & - & - & - & - & - & - & - & $\square$ & ! & - & - & - & - & - & - & - \\
\hline
\end{tabular}


Table 1 Host specificity of viruses (Ot stands for Ostreococcus tauri, Ol is 0 . lucimarinus, Om is 0 . mediterraneus, Osp is Ostreococcus sp., and Bp is B. prasinos). - no lysis; $\square$ lysis (isolate from this host); - lysis (Continued)

\begin{tabular}{lllllllllllllllllllllllllll}
\hline OtV573 & - & - & - & - & - & - & - & - & - & - & - & - & - & $\square$ & - & - & - & - & $\square$ & - & - & - \\
OtV22 & - & - & - & - & - & - & - & - & - & - & - & - & - & - & - & - & - & $\square$ & - & - & - & - \\
OtV343 & - & - & - & - & - & - & - & - & - & - & - & - & - & - & - & - & $\square$ & - & - & - & - & - \\
OtV344 & - & - & - & - & - & - & - & - & - & - & - & - & - & - & - & - & $\square$ & - & - & - & - & - \\
OtV304 & - & - & - & - & - & - & - & - & - & - & - & - & - & - & - & $\square$ & - & - & - & - & - & - \\
OmV63 & - & - & - & - & - & - & - & - & - & - & - & - & - & - & - & - & - & - & - & $\square$ & - & - \\
OmV64 & - & - & - & - & - & - & - & - & - & - & - & - & - & - & - & - & - & - & - & $\square$ & - & - \\
OmV67 & - & - & - & - & - & - & - & - & - & - & - & - & - & - & - & - & - & - & - & $\square$ & - & - \\
BpV1 & - & - & - & - & - & - & - & - & - & - & - & - & - & - & - & - & - & - & - & - & $\square$ & - \\
BatV3 & - & - & - & - & - & - & - & - & - & - & - & - & - & - & - & - & - & - & - & - & - & $\square$ \\
\hline
\end{tabular}

observed in Ostreococcus, clustering strains in the clades A, C and D defined by [17] (no strain from clade B was included in the present analysis). Three well-supported clades are also found in Micromonas. Bathycoccus is much more homogeneous, and the only two strains retained are closely related. However, the $18 \mathrm{~S}$ sequence from RCC1105 (Bathycoccus) included an intron that was removed for the phylogenetic analysis.

The phylogenetic tree of viral strains (Figure 1) suggests that viruses from Ostreococcus and Micromonas form a paraphyletic group, i.e. viruses from Micromonas are derived from Ostreococcus viruses. However, the Micromonas virus clade is strongly supported and contains several well-defined clades.

\section{Cophylogeny}

The global congruence between trees using the distancebased approach ParaFit was highly significant $(\mathrm{P}=0.001$, see Table 4 for all results on cophylogenetic analyses), as were all the 138 individual host-virus links (each P-value is below 0.05). The event-based analysis with Jane, taking tree topologies into account, also yielded a highly significant global congruence between host and virus phylogenetic trees $(\mathrm{P}=0.001)$, confirming the ParaFit analysis. The

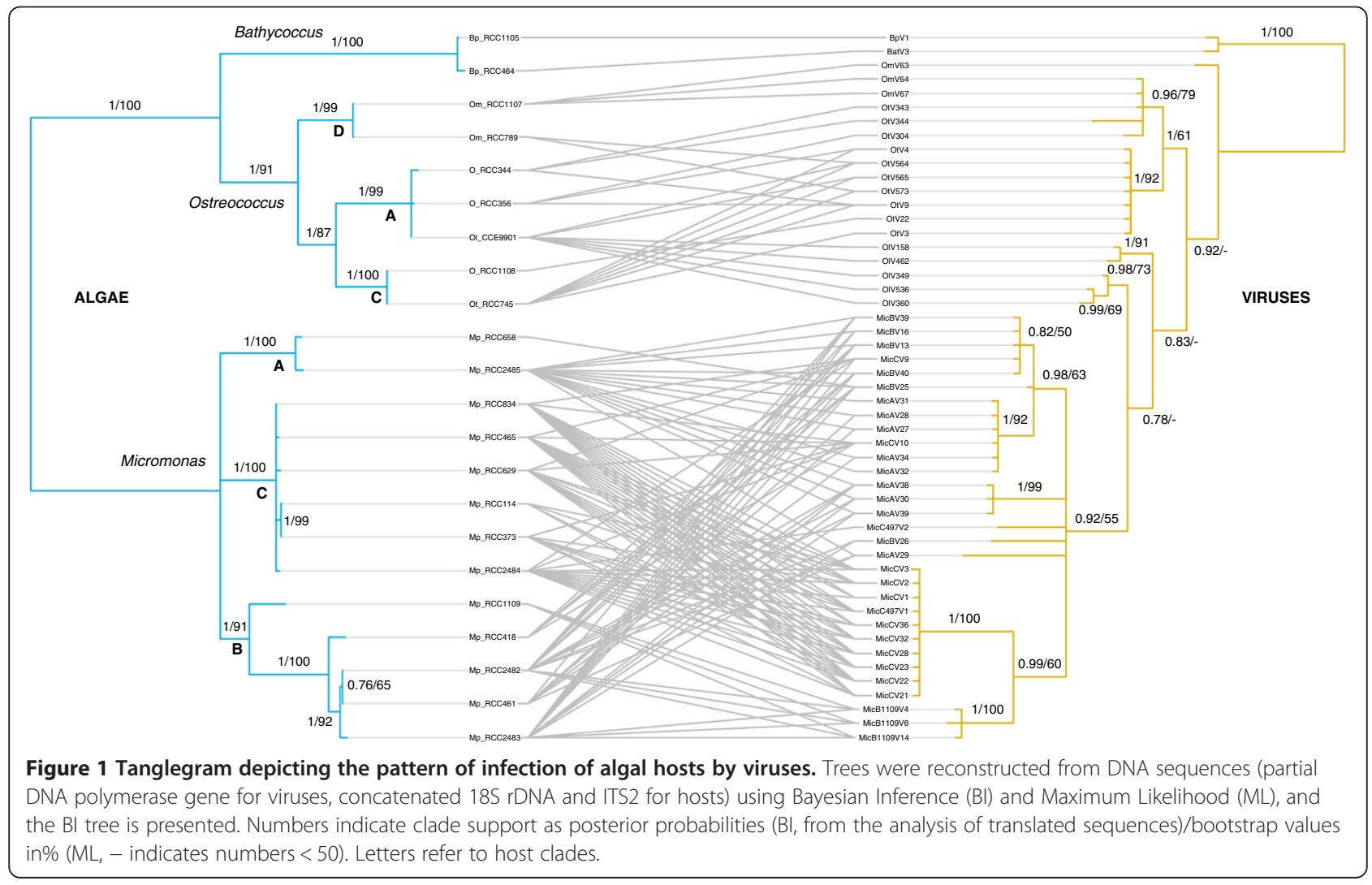


Table 2 Host strains used in this study (RCC = Roscoff Culture Collection)

\begin{tabular}{|c|c|c|c|c|c|c|}
\hline Host species & Clade & $\begin{array}{l}\text { Strain code } \\
\text { in RCC }\end{array}$ & $\begin{array}{l}\text { Alternative strain code } \\
\text { (other culture collections) }\end{array}$ & Isolation site & $\begin{array}{l}\text { Isolation date } \\
\text { (dd-mm-yyyy) }\end{array}$ & $\begin{array}{l}\text { Reference and/or } \\
\text { accession number }\end{array}$ \\
\hline \multirow[t]{2}{*}{$\overline{M p}$} & $A$ & 2485 & & Atlantic Ocean & $11-07-1980$ & This study, KF501024 \\
\hline & & & & $\left(38^{\circ} 42^{\prime} \mathrm{N}, 72^{\circ} 22 \mathrm{~W}\right)$ & & \\
\hline $\mathrm{Mp}$ & A & 658 & CS-170 & Pacific Ocean, West Australia & 01-01-1982 & This study, KF501030 \\
\hline $\mathrm{Mp}$ & B & 2482 & & Mediterranean Sea, Italy & 08-04-1993 & This study, KF501032 \\
\hline $\mathrm{Mp}$ & B & 2483 & & Mediterranean Sea, Italy & 08-01-1997 & This study, KF501033 \\
\hline \multirow[t]{2}{*}{$\mathrm{Mp}$} & B & 418 & & English Channel & $14-06-2001$ & This study, KF501026 \\
\hline & & & & $\left(48^{\circ} 37^{\prime} \mathrm{N}, 3^{\circ} 51 \mathrm{~W}\right)$ & & \\
\hline \multirow[t]{2}{*}{$\mathrm{Mp}$} & B & 461 & & English Channel & $14-06-2001$ & This study, KF501027 \\
\hline & & & & $\left(48^{\circ} 37^{\prime} \mathrm{N}, 3^{\circ} 51 \mathrm{~W}\right)$ & & \\
\hline \multirow[t]{2}{*}{$\mathrm{Mp}$} & B & 1109 & & Mediterranean Sea, Leucate lagoon & $28-07-2006$ & This study, KF501031 \\
\hline & & & & $\left(42^{\circ} 48^{\prime} \mathrm{N}, 3^{\circ} 1^{\prime} \mathrm{E}\right)$ & & \\
\hline \multirow[t]{2}{*}{$\mathrm{Mp}$} & C & 2484 & & Mediterranean Sea, Spain & $18-04-2002$ & This study, KF501034 \\
\hline & & & & $\left(41^{\circ} 43^{\prime} \mathrm{N}, 3^{\circ} 33^{\prime} \mathrm{E}\right)$ & & \\
\hline \multirow[t]{2}{*}{$\mathrm{Mp}$} & C & 834 & CCMP1545, PLY 27 & English Channel & $13-04-1950$ & [28]; AY954994 \\
\hline & & & & $\left(50^{\circ} 36^{\prime} \mathrm{N}, 3^{\circ} 57 \mathrm{~W}\right)$ & & \\
\hline \multirow[t]{2}{*}{$\mathrm{Mp}$} & $\mathrm{C}$ & 629 & & North Sea, Germany & $17-01-2001$ & This study, KF501018 \\
\hline & & & & $\left(54^{\circ} 11^{\prime} \mathrm{N}, 7^{\circ} 54^{\prime} \mathrm{E}\right)$ & & \\
\hline \multirow[t]{2}{*}{$\mathrm{Mp}$} & C & 465 & & English Channel & $13-06-2001$ & This study, KF501028 \\
\hline & & & & $\left(48^{\circ} 37^{\prime} \mathrm{N}, 4^{\circ} 17 \mathrm{~W}\right)$ & & \\
\hline \multirow[t]{2}{*}{$\mathrm{Mp}$} & C & 373 & & Baltic Sea, Skagerrak & 03-01-2001 & This study, KF501025 \\
\hline & & & & $\left(58^{\circ} 11^{\prime} \mathrm{N}, 9^{\circ} 6^{\prime} \mathrm{E}\right)$ & & \\
\hline \multirow[t]{2}{*}{$\mathrm{Mp}$} & C & 114 & CCMP490 & Atlantic Ocean, USA & 18-06-1964 & [22], AY955004 \\
\hline & & & & $\left(41^{\circ} 31^{\prime} \mathrm{N}, 70^{\circ} 40 \mathrm{~W}\right)$ & & \\
\hline \multirow[t]{2}{*}{ Ot } & C & 745 & & Mediterranean Sea, Thau lagoon & 03-05-1995 & [19], CAID01000012 \\
\hline & & & & $\left(43^{\circ} 24^{\prime} \mathrm{N}, 3^{\circ} 36^{\prime} \mathrm{E}\right)$ & & \\
\hline \multirow[t]{2}{*}{$\mathrm{Ol}$} & A & & CCE9901, CCMP2972 & North Pacific, California & 01-01-1999 & [20], AY329636 \\
\hline & & & & $\left(32^{\circ} 90^{\prime} \mathrm{N}, 117^{\circ} 25 \mathrm{~W}\right)$ & & \\
\hline \multirow[t]{2}{*}{ O } & A & 344 & & English Channel & $04-12-2000$ & [16], AY425307 (18S); \\
\hline & & & & $\left(48^{\circ} 45^{\prime} \mathrm{N}, 3^{\circ} 57^{\prime} \mathrm{W}\right)$ & & \\
\hline \multirow[t]{2}{*}{$\mathrm{O}$} & A & 356 & & North Atlantic, Morocco & 09-12-1999 & [16], AY425308 (18S); \\
\hline & & & & $\left(30^{\circ} 8^{\prime} \mathrm{N}, 10^{\circ} 3 \mathrm{~W}\right)$ & & \\
\hline \multirow[t]{2}{*}{ O } & C & 1108 & & Mediterranean Sea, Banyuls Bay & $01-02-2006$ & [18]; GQ426332 \\
\hline & & & & $\left(42^{\circ} 29^{\prime} \mathrm{N}, 3^{\circ} 8^{\prime} \mathrm{E}\right)$ & & \\
\hline \multirow[t]{2}{*}{ Om } & $\mathrm{D}$ & 789 & & Mediterranean Sea, Spain & $28-02-2001$ & [16], AY425313 (18S); This \\
\hline & & & & $\left(41^{\circ} 43^{\prime} \mathrm{N}, 3^{\circ} 33^{\prime} \mathrm{E}\right)$ & & TS) \\
\hline Om & D & 1107 & & Mediterranean Sea, $\left(43^{\circ} 3^{\prime} \mathrm{N}, 2^{\circ} 59^{\prime} \mathrm{E}\right)$ & $01-01-2006$ & [21], JN862902 \\
\hline \multirow[t]{2}{*}{$\mathrm{Bp}$} & & 1105 & & Mediterranean Sea, Banyuls Bay & 01-01-2006 & [29], JX625115 \\
\hline & & & & $\left(42^{\circ} 29^{\prime} \mathrm{N}, 3^{\circ} 8^{\prime} \mathrm{E}\right)$ & & \\
\hline \multirow[t]{2}{*}{$\mathrm{Bp}$} & & 464 & & English Channel & $09-07-2000$ & This study, KF501036 \\
\hline & & & & $\left(48^{\circ} 45^{\prime} \mathrm{N}, 3^{\circ} 57 \mathrm{~W}\right)$ & & \\
\hline
\end{tabular}

$\mathrm{Mp}=$ Micromonas pusilla, $\mathrm{Ot}=$ Ostreococcus tauri, $\mathrm{O}=$ Ostreococcus $\mathrm{sp}, \mathrm{Ol}=$ Ostreococcus lucimarinus, $\mathrm{Om}=$ Ostreococcus mediterraneus, $\mathrm{Bp}=$ Bathycoccus prasinos. RCC2482, 2483, 2484 and 2485 are clonal strains isolated from RCC828, RCC829, RCC497 and RCC 451, respectively. 
Table 3 Data on virus strains used in this study (RCC: Roscoff Culture Collection)

\begin{tabular}{|c|c|c|c|c|}
\hline Strain name in RCC & Original strain name & $\begin{array}{l}\text { Isolation date } \\
\text { (dd-mm-yyyy) }\end{array}$ & Isolation site & $\begin{array}{l}\text { Reference and/or } \\
\text { accession number }\end{array}$ \\
\hline 2066 & MicAV27 & $10-11-2009$ & SOMLIT-Astan $\left(48^{\circ} 46^{\prime} 18^{\prime \prime} \mathrm{N}, 3^{\circ} 58^{\prime} 6^{\prime \prime} \mathrm{W}\right)$ & {$[8]$, KF378571 } \\
\hline 2067 & MicAV28 & $10-11-2009$ & SOMLIT-Astan $\left(48^{\circ} 46^{\prime} 18^{\prime \prime} \mathrm{N}, 3^{\circ} 58^{\prime} 6^{\prime \prime} \mathrm{W}\right)$ & This study, KF500985 \\
\hline 2068 & MicAV29 & $10-11-2009$ & SOMLIT-Astan $\left(48^{\circ} 46^{\prime} 18^{\prime \prime} \mathrm{N}, 3^{\circ} 58^{\prime} 6^{\prime \prime} \mathrm{W}\right)$ & [8], KF378572 \\
\hline 2069 & MicAV30 & $10-11-2009$ & Ilot St-Anne $\left(48^{\circ} 41^{\prime} 17^{\prime \prime} \mathrm{N}, 3^{\circ} 57^{\prime} 27^{\prime \prime} \mathrm{W}\right)$ & {$[8]$, KF378573 } \\
\hline 2070 & MicAV31 & $11-11-2009$ & Ilot St-Anne $\left(48^{\circ} 41^{\prime} 17^{\prime \prime} \mathrm{N}, 3^{\circ} 57^{\prime} 27^{\prime \prime} \mathrm{W}\right)$ & This study, KF500986 \\
\hline 2071 & MicAV32 & $11-11-2009$ & Ilot St-Anne (484 $\left.41^{\prime} 17^{\prime \prime} \mathrm{N}, 3^{\circ} 57^{\prime} 27^{\prime \prime} \mathrm{W}\right)$ & This study, KF500987 \\
\hline 2073 & MicAV34 & $12-11-2009$ & Ilot St-Anne $\left(48^{\circ} 41^{\prime} 17^{\prime \prime} \mathrm{N}, 3^{\circ} 57^{\prime} 27^{\prime \prime} \mathrm{W}\right)$ & This study, KF500988 \\
\hline 2075 & MicAV38 & $12-10-2009$ & SOMLIT-Astan $\left(48^{\circ} 46^{\prime} 18^{\prime \prime} \mathrm{N}, 3^{\circ} 58^{\prime} 6^{\prime \prime} \mathrm{W}\right)$ & This study, KF500989 \\
\hline 2076 & MicAV39 & $12-10-2009$ & SOMLIT-Astan $\left(48^{\circ} 46^{\prime} 18^{\prime \prime} \mathrm{N}, 3^{\circ} 58^{\prime} 6^{\prime \prime} \mathrm{W}\right)$ & This study, KF500990 \\
\hline 2082 & MicBV13 & 20-03-2009 & SOMLIT-Astan $\left(48^{\circ} 46^{\prime} 18^{\prime \prime} \mathrm{N}, 3^{\circ} 58^{\prime} 6^{\prime \prime} \mathrm{W}\right)$ & This study, KF500993 \\
\hline 2085 & MicBV16 & 20-03-2009 & SOMLIT-Astan (4846' 18" N, 358' 6'W) & This study, KF500994 \\
\hline 2093 & MicBV25 & $18-05-2009$ & SOMLIT-Astan $\left(48^{\circ} 46^{\prime} 18^{\prime \prime} \mathrm{N}, 3^{\circ} 58^{\prime} 6^{\prime \prime} \mathrm{W}\right)$ & This study, KF500995 \\
\hline 2094 & MicBV26 & $18-05-2009$ & SOMLIT-Astan (4846' 18" N, 358' 6'W) & [8], KF378576 \\
\hline 2099 & MicBV39 & $16-04-2009$ & SOMLIT-Astan (4846' 18" N, 358' 6'W) & {$[8]$, KF378578 } \\
\hline 2100 & MicBV40 & $16-04-2009$ & SOMLIT-Astan (4846 $\left.18^{\prime \prime} \mathrm{N}, 3^{\circ} 58^{\prime} 6^{\prime \prime} \mathrm{W}\right)$ & This study, KF500996 \\
\hline \multirow[t]{2}{*}{2199} & MicB1 109V4 & 28-09-2009 & SOMLIT-Astan (4846' 18" N, 358' 6"W) & This study, KF500991 \\
\hline & MicB1109V6 & 28-09-2009 & SOMLIT-Astan (4846' 18" N, 358' 6'W) & This study, KF500992 \\
\hline 2206 & MicB1109V14 & 28-09-2009 & SOMLIT-Astan (4846' 18" N, 358' 6'W) & [8], KF378564 \\
\hline 2125 & MicCV1 & $05-02-2009$ & SOMLIT-Astan $\left(48^{\circ} 46^{\prime} 18^{\prime \prime} \mathrm{N}, 3^{\circ} 58^{\prime} 6^{\prime \prime} \mathrm{W}\right)$ & This study, KF500997 \\
\hline 2126 & MicCV2 & 05-02-2009 & SOMLIT-Astan (4846' 18" N, 358' 6"W) & This study, KF500998 \\
\hline 2127 & $\mathrm{MicCV} 3$ & 05-02-2009 & SOMLIT-Astan (4846' 18" N, 358' 6'W) & This study, KF500999 \\
\hline 2131 & MicCV9 & 03-04-2009 & SOMLIT-Astan (4846' 18" N, 358' 6'W) & [8], KF378580 \\
\hline 2132 & MicCV10 & 03-04-2009 & SOMLIT-Astan (4846' 18" N, 358' 6'W) & This study, KF501000 \\
\hline 2135 & MicCV21 & 04-05-2009 & SOMLIT-Astan (4846' 18" N, 358' 6'W) & This study, KF501001 \\
\hline 2136 & MicCV22 & 04-05-2009 & SOMLIT-Astan (4846' 18" N, $\left.3^{\circ} 58^{\prime} 6^{\prime \prime} \mathrm{W}\right)$ & This study, KF501002 \\
\hline 2137 & MicCV23 & 04-05-2009 & SOMLIT-Astan (4846' 18" N, 358' 6'W) & This study, KF501003 \\
\hline 2142 & MicCV28 & $18-05-2009$ & SOMLIT-Astan $\left(48^{\circ} 46^{\prime} 18^{\prime \prime} \mathrm{N}, 3^{\circ} 58^{\prime} 6^{\prime \prime} \mathrm{W}\right)$ & This study, KF501004 \\
\hline 2146 & MicCV32 & 02-06-2009 & SOMLIT-Astan $\left(48^{\circ} 46^{\prime} 18^{\prime \prime} \mathrm{N}, 3^{\circ} 58^{\prime} 6^{\prime \prime} \mathrm{W}\right)$ & [8], KF378579 \\
\hline 2150 & MicCV36 & $14-08-2009$ & SOMLIT-Astan (4846' 18" N, 358' 6'W) & This study, KF501005 \\
\hline 2167 & MicC497V1 & $18-05-2009$ & SOMLIT-Astan (4846' 18" N, 358' 6'W) & [8], KF378567 \\
\hline \multirow[t]{13}{*}{2168} & MicC497V2 & $18-05-2009$ & SOMLIT-Astan (4846' 18" N, 358' 6'W) & [8], KF378566 \\
\hline & Olv158 & $01-16-2008$ & Mediterranean Sea, Leucate lagoon $\left(42^{\circ} 48 \mathrm{~N}, 3^{\circ} 1^{\prime \prime} \mathrm{E}\right)$ & [27], GQ412099 \\
\hline & Olv349 & $09-26-2008$ & English Channel $\left(48^{\circ} 45^{\prime} \mathrm{N}, 3^{\circ} 57 \mathrm{~W}\right)$ & [27], GQ412082 \\
\hline & Olv360 & $10-30-2008$ & South Pacific, Chili $\left(36^{\circ} 32^{\prime} \mathrm{S}, 72^{\circ} 56 \mathrm{~W}\right)$ & [27], GQ412085 \\
\hline & Olv462 & $09-26-2008$ & Mediterranean Sea, Banyuls Bay $\left(42^{\circ} 29^{\prime} \mathrm{N}, 3^{\circ} 8^{\prime} \mathrm{E}\right)$ & [27], GQ412091 \\
\hline & Olv536 & $10-20-2008$ & English Channel $\left(48^{\circ} 45^{\prime} \mathrm{N}, 3^{\circ} 57 \mathrm{~W}\right)$ & [27], GQ412096 \\
\hline & OtV3 & $01-24-2006$ & Mediterranean Sea, La Palme lagoon (4257'18.04"N, $\left.3^{\circ} 0^{\prime} 3.56^{\prime \prime} \mathrm{E}\right)$ & [13], FJ267504 \\
\hline & OtV4 & $01-24-2006$ & Mediterranean Sea, La Palme lagoon (4257'18.04"N, 30'3.56"E) & This study, KF501006 \\
\hline & OtV9 & $13-02-2006$ & Mediterranean Sea, Thau lagoon ( $\left.43^{\circ} 24^{\prime} \mathrm{N}, 03^{\circ} 36^{\prime} \mathrm{E}\right)$ & [30], JN225859 \\
\hline & OtV22 & $04-20-2006$ & Mediterranean Sea, Bages lagoon & [13], FJ267497 \\
\hline & OtV304 & 08-06-2008 & Mediterranean Sea, Leucate lagoon $\left(42^{\circ} 48 \mathrm{~N}, 3^{\circ} 1^{\prime} \mathrm{E}\right)$ & This study, KF501007 \\
\hline & OtV343 & $09-26-2008$ & Mediterranean Sea, Banyuls Bay $\left(42^{\circ} 29^{\prime} \mathrm{N}, 3^{\circ} 8^{\prime} \mathrm{E}\right)$ & This study, KF501008 \\
\hline & OtV344 & $09-26-2008$ & Mediterranean Sea, Banyuls Bay $\left(42^{\circ} 29^{\prime} \mathrm{N}, 3^{\circ} 8^{\prime} \mathrm{E}\right)$ & This study, KF501009 \\
\hline
\end{tabular}


Table 3 Data on virus strains used in this study (RCC: Roscoff Culture Collection) (Continued)

\begin{tabular}{|c|c|c|c|c|}
\hline & OtV564 & 27-03-2009 & Mediterranean Sea, La Palme lagoon (42 $\left.57^{\prime} 18.04^{\prime \prime} \mathrm{N}, 3^{\circ} 0^{\prime} 3.56^{\prime \prime} \mathrm{E}\right)$ & This study, KF501010 \\
\hline & OtV565 & 27-03-2009 & Mediterranean Sea, La Palme lagoon (4257'18.04"N, 30'3.56"E) & This study, KF501011 \\
\hline & Otv573 & 27-03-2009 & Mediterranean Sea, La Palme lagoon (4257'18.04"N, 30'3.56"E) & This study, KF501012 \\
\hline & OmV63 & $01-31-2007$ & Mediterranean Sea, La Palme lagoon (4257'18.04"N, 30'3.56"E) & [13], FJ267501 \\
\hline & OmV64 & $01-31-2007$ & Mediterranean Sea, La Palme lagoon (4257'18.04"N, 30'3.56"E) & [13], FJ267502 \\
\hline & OmV67 & 06-01-2007 & Mediterranean Sea, Leucate lagoon $\left(42^{\circ} 48^{\prime} \mathrm{N}, 3^{\circ} 1^{\prime} \mathrm{E}\right)$ & [13], FJ267500 \\
\hline & BpV1 & $10-31-2007$ & Mediterranean Sea, Banyuls Bay $\left(42^{\circ} 27^{\prime} \mathrm{N}, 3^{\circ} 32^{\prime} \mathrm{E}\right)$ & [11], NC_014765 \\
\hline 2211 & BatV3 & 04-04-2009 & English Channel $\left(48^{\circ} 37^{\prime} \mathrm{N}, 4^{\circ} 17 \mathrm{~W}\right)$ & This study, KF501013 \\
\hline
\end{tabular}

complexity of this host-symbiont system precludes the establishment of any intelligible coevolutionary scenario. Because of this complexity, we performed three partial analyses in addition to the full dataset: only Micromonas strains and their viruses, Bathycoccus and Ostreococcus strains and their viruses, and only Ostreococcus strains and their viruses. Analyses with ParaFit gave a significant global congruence $(\mathrm{P}=0.001)$ between host and parasite trees for the Micromonas dataset (78/111 significant links) and the Bathycoccus and Ostreococcus dataset (12/26 significant links) but some individual host-virus links were found non-significant. For the Ostreococcus dataset, the global fit was not significant $(\mathrm{P}=0.11 ; 1 / 25$ significant links). In Jane analyses, the global congruence was significant for the Micromonas dataset $(\mathrm{P}=0.001)$, but not for the Bathycoccus-Ostreococcus dataset $(\mathrm{P}=0.1)$ and the Ostreococcus dataset $(\mathrm{P}=0.46)$. Note that the results were similar with the trees obtained from BI or ML trees, and using a virus tree where the monophyly of the viruses of Micromonas, Ostreococcus and Bathycoccus were each enforced (built with the same method and parameters, and not significantly different from the tree on Figure 1 (Kishino-Hasegawa test: $\mathrm{P}=0.330$; Shimodeira-Hasegawa test: $\mathrm{P}=0.160$. Both tests were performed in PAUP with distributions generated from 1000 boostrap replicates by the resampling estimated log-likelihood method using a fully optimized model)).

\section{Discussion}

Three main results emerge from the present study: (1) prasinoviruses are specific to their host genus (2); within a genus, their viruses are generally specific to a clade (i.e. they can infect different host strains that belong to the same clade) (3); the cophylogenetic analysis using ParaFit and Jane revealed significant patterns of associations between host and virus phylogenetic trees and then suggests the existence of a common macroevolutionary scenario between Mamiellophyceae and their viruses.

While viruses can often infect several host species or genetic clades, a phylogenetic specificity is nevertheless clearly observed, i.e. prasinoviruses tend to infect related host strains, as observed in Ostreococcus strains and their viruses [8]. This has also been previously observed in Micromonas viruses [31,32], and other virus-microalgae associations [4]. In the absence of studies determining the species of most of the host strains used, host clade is the best proxy we currently have for putative host species or ecotype $[17,21,22]$. By doing so, we observe that most Prasinovirus strains are species-specific, with the more generalist viruses tending to infect more related host species (see Figure 1 and Table 1). Given that high dispersion of hosts and viruses [27] allow them to enter in contact, it is likely that there is no ecological barrier to host switch. This suggests that mechanistic processes preclude viruses from infecting distantly related host species. Such inner structural limiting factors were also observed in the related chloroviruses [33]. We hypothesize that intrinsic factors affecting specificity should exist otherwise large host ranges would be common, as they would allow viruses to maintain themselves even when the populations of some of their host species are subjected to fluctuations, which is not observed. This is especially relevant, given that low density populations of host Mamiellales are often found in oligotrophic environments [34,35].

Table 4 Results of the cophylogenetic analyses with ParaFit ("links" refer to individual host-virus associations) and Jane (costs for individual events: Cospeciation =0, Duplication =1, Host-switch = 2, Loss = 1, Failure to diverge $=1$ )

\begin{tabular}{|c|c|c|c|}
\hline & \multicolumn{2}{|c|}{ ParaFit } & \multirow{2}{*}{$\begin{array}{c}\text { Jane } \\
\text { Global cost (P-value }\end{array}$} \\
\hline & P-value for global fit & Number of significant links/total & \\
\hline All & 0.001 & $138 / 138$ & $236(0.001)$ \\
\hline Micro & 0.01 & $78 / 111$ & $183(0.001)$ \\
\hline Bathy-Ostreo & 0.001 & $12 / 26$ & $41(0.1)$ \\
\hline
\end{tabular}

"All" refers to the full dataset, "Micro" to the association between only Micromonas hosts and their viruses, "Bathy-Ostreo" to Bathycoccus and Ostreococcus hosts and their viruses. All statistical tests were performed with 999 permutations. 
Some host strains (e.g. Micromonas RCC2484 or Ostreococcus tauri RCC745) are susceptible to a wider range of viruses than others (e.g. Micromonas RCC804 or Ostreococcus RCC1108). This may be related to lower resistance of these Mamiellale strains to viruses, as previously observed by Thomas et al. [30], who showed experimentally that resistance to a given viral strain was associated to increased sensitivity to other viral strains as well as to loss in fitness (i.e. slower growth) compared to susceptible host lines, and a balance between resistance or susceptibility was observed in culture, depending on the partners present. This trade-off, combined with the host range of particular viruses, results in the complex pattern of specificity/sensitivity observed in the present study. The highest sensitivity observed here in Micromonas perhaps reflects the higher number of host and virus strains found in this genus.

In the last three decades, many studies investigating cospeciation in host-symbiont systems e.g. [36-40], see [9] have been published, and report various analytical methods [40-46]. However, while a number of host-virus system have been studied to date in a cophylogenetic framework [47-50], to our best knowledge none were carried out on an aquatic association. In a vast aquatic environment, such as the open sea, the barriers to host switching can be seen as generally weaker than in a structured terrestrial ecosystem where local adaptation can occur more easily [51], especially given the wide dispersal of hosts and viruses in the marine ecosystem. Any cospeciation signal is thus more likely due to close adaptation to the host than to the impossibility to switch hosts.

A significant global signal of cospeciation was found with all methods used, suggesting that Prasinovirus evolution is in part driven by the evolution of their hosts, or at least that related viruses tend to use related hosts. When partitioning the dataset into Micromonas strains and their viruses, Bathycoccus-Ostreococcus strains and their viruses, and Ostreococcus strains and their viruses, results were slightly different. The global fit analysis with ParaFit found a significant congruence in all cases, while the event-based analysis with Jane found a non-significant congruence for the Bathycoccus-Ostreococcus and the Ostreococcus datasets. This lack of significant signal may reflect a genuine lack of cophylogenetic signal, or may be due to a lower statistical power with less data (because the null hypothesis is the absence of congruence). The differing results obtained by ParaFit and Jane for Bathycoccus-Ostreococcus and Ostreococcus only might also arise because the genetic distances (used by ParaFit) do not always correlate with phylogenetic (patristic) distances as used in Jane. Thus genetically close viruses tend to colonize close hosts but this may not be always the case at a phylogenetic point of view supporting the hypothesis that viruses can switch to different, but not too distantly related, host strains. The global significance observed for the complete dataset with all methods confirms the genus-specificity of viruses: Bathycoccus, Ostreococcus and Micromonas have their own viruses that do not cross the genus boundaries with detectable frequencies. Within each genus, even if viruses tend to be clade-specific, several strains possess a wide intrageneric, and probably interspecific, host range. This is especially true in Micromonas viruses where several strains can infect hosts from the three clades, while this pattern is much less frequent in Ostreococcus viruses. However, this is not strong enough to break the significant cophylogenetic congruence between Micromonas strains and their viruses ( $P=0.01$ ), while between Ostreococcus-Bathycoccus and their viruses the cophylogenetic signal is not significant, as well as between Ostreococcus and their viruses. The different results obtained with ParaFit and Jane for the Ostreococcus-Bathycoccus dataset may in part be due to the different ways these methods works: ParaFit relies only on distances and the influence of the tree topology on the outcome is far less important than in a method such as Jane. However, this issue exists for the Micromonas as well as for the Bathycoccus-Ostreococcus and Ostreococcus datasets (which contain less taxa, then less data, decreasing the statistical power), and the cophylogenetic congruence in the Bathycoccus-Ostreococcus dataset is only slightly below the significance threshold with Jane. Duplication and sorting probably also play a role here to explain the lack of topological congruence between trees. However, while viruses seems currently unable to switch from a genus to another, the absence of match between host and virus phylogenetic trees at the genus level suggests an early host-switch from Bathycoccus to Micromonas whose colonization by prasinoviruses would then be more recent. That could explain the more general pattern of association between Micromonas strains and their viruses with strains displaying a cross-clade specificity.

In most previous cophylogenetic analyses on hostvirus systems, a significant cospeciation signal was found $[47,49,50,52-64]$. However complex cophylogenetic histories were often estimated, mixing codivergence with host-switches, duplication and losses [50] and in some cases, no significant cospeciation signal was inferred $[48,49,61,65,66]$. The general tendency is however that virus evolution is strongly linked to that of their hosts, which is coherent with the results found in the present study, in a totally different environment to those previously investigated for viruses of eukaryotes. The tendency to cospeciate with hosts is thus probably due to intrinsic features of viruses (e.g. mechanistic causes such as molecular characteristics constraining the use of specific hosts) rather than to ecological barriers.

The presence of a cospeciation signal does not necessarily imply real cospeciation, i.e. a significant amount of 
concomitant speciation in hosts and their parasites. For example, a host switch to a sister host species followed by a speciation of the parasite produces a false cospeciation pattern $[58,65,67]$. If this process is common across the whole host-parasite association, a spurious cospeciation signal might be found when comparing topologies [39], and this may lead to an overestimation of cospeciation patterns by cophylogenetic methods [68]. To support temporal cospeciation, time must be taken into account, ideally from independent assessments of speciation time in hosts and their viruses over the time period. This is rarely possible because the inference for symbionts is generally made from host data [69]. Another approach is to rely on the estimation of molecular evolutionary rate in viruses to date speciation events [65]. Weaker, but nevertheless strong evidence, is provided the comparison of evolutionary divergence in cospeciating pairs. Such pairs ("copaths") are identified using methods such as Jane or TreeMap, because cospeciation events need to be inferred first. Copaths take into account the branch lengths connecting hosts and their cospeciating symbionts to these cospeciation events. If a correlation is found between copaths in hosts and corresponding viruses [70], i.e. via a significant linear regression when including all pairs, this supports cospeciation. In addition, showing that the intercept of this regression line is not different from 0 is again strong evidence for a cospeciation pattern. Whether or not such a pattern can be found depends on the cophylogenetic scenario considered (cospeciating pairs and corresponding copaths are different for each scenario), and as the number of scenarios is very high in the present host-virus system, it is not possible to study each of them to investigate if real cospeciation has taken place. The significant cospeciation signal observed here should then be considered with caution, and seems mainly due to the genus-level specificity. Nevertheless, the strength of the cophylogenetic signal observed in this analysis supports the hypothesis that virus evolution is in part driven by their hosts. If cospeciation is indeed happening within this host-virus association, it would imply that prasinoviruses evolve more slowly than their hosts, as [11] have shown, based on genomic data, that the evolutionary divergence between hosts is much higher than that between corresponding viruses. This host-virus system would then be a peculiar case among host-symbiont systems, where symbionts generally evolve faster than their hosts [9].

\section{Conclusion}

The data and analyses provided in this paper support that prasinoviruses, while generally highly host specific, sometimes display a wide host range, with some strains able to infect hosts from different species. This can have important consequences when considering the role of viruses in microbial ecology.

A significant cospeciation signal between prasinoviruses and their hosts has been found in the cophylogenetic analyses performed in the present study, but their joint evolutionary history is complex, certainly involving host switches, duplication and losses, in addition to cospeciation events. Because it has been shown in a previous study that host genomes diverge more than corresponding viruses, additional data and analyses are needed to identify cospeciation events and to estimate the timing of these events, in order to be able to compare evolutionary rates in prasinoviruses and their hosts.

\section{Methods}

\section{Hosts and viruses isolation}

Hosts and viruses were isolated from environmental samples and kept in culture collections in Banyuls-sur-Mer and Roscoff. All hosts except Ostreococcus lucimarinus (CCE9901) and part of the viruses are referred to by their RCC (Roscoff Culture Collection) numbers (see Tables 2 and 3). Given the uncertainties concerning the species status of the genetic clades within Micromonas, Ostreococcus and Bathycoccus, we chose to use the currently accepted names Micromonas pusilla and Bathycoccus prasinos for all Micromonas and Bathycoccus strains respectively, and Ostreococcus sp., O. lucimarinus, O. tauri and O. mediterraneus for the strains belonging to the different Ostreococcus species. Prefixes $\mathrm{Bp}_{-}, \mathrm{Mp}_{-}$, and $\mathrm{O}_{-}, \mathrm{Ot}_{-}$and $\mathrm{Om}_{\text {- were }}$ added to the RCC numbers to designate respectively Bathycoccus prasinos, Micromonas pusilla, and Ostreococcus sp., O. tauri and O. mediterraneus strains (while O. lucimarinus is named Ol_CCE9901). Viruses from Bathycoccus, Micromonas, Ostreococcus are respectively named $\mathrm{BatV}$ or $\mathrm{BpV}$, $\mathrm{MicV}$ or $\mathrm{MpV}$, and $\mathrm{OtV}, \mathrm{OmV}$ or OlV with numbers and letters corresponding to strains and the clade containing the host strain used for isolation. For example, MicAV31, refers to a Micromonas virus (strain 31) isolated from a clade A host.

Virus isolation and purification were obtained by a plating technique $[7,13]$. This method allowed us to visualize and pick off individual lysis plaques. Succinctly, seawater samples were filtered by gravity through membranes with a porosity of $3 \mu \mathrm{m}$ then $0.45 \mu \mathrm{m}$. Filtrate were mixed with K-medium, growing host culture, a solution of hot agarose and poured in a Petri dish. Few days after plating, plaques appeared inside the agarose gel, they were picked off, mixed with $400 \mu \mathrm{l}$ of a solution of $\mathrm{MgSO}_{4}$ (SM buffer; CSH Protocols; 2006; doi:10.1101/pdb.rec466) and conserved at $4{ }^{\circ} \mathrm{C}$. This technique ensures the presence of active viral particles in the isolate.

Isolation and growth of host strains was performed as in [18]. Briefly, seawater samples were mixed with Keller's medium after filtration, and cultured for about 3 weeks. 
Cultures were then plated out to obtain individual clones on gel-solidified Keller's medium or on L1 medium [71]. Colonies were then picked off for further growth after 3 weeks. Clonality was obtained on semi-solid agar plates: cells from the original strains were cultured in semi-solid agar $\mathrm{K}$ medium and individual colonies were picked off and transferred into new semi-solid agar medium. This process was repeated 2 or 3 times.

\section{Host specificity}

We first assessed the pattern of host specificity, i.e. the host range of each viral strain investigated. Prasinoviruses infect hosts that can be cultured on plates [7], allowing host specificity to be tested experimentally [8]. We first tested the ability of each viral strain to grow on a plated clonal culture of each putative host strain, then kept for the subsequent analyses only host strains that supported growth of at least one viral strain. Plates of hosts were prepared $\left(7 \mathrm{ml}\right.$ of K-medium, $8 \mathrm{ml}$ of a $3.10^{7}$ cells $/ \mathrm{ml}$ of a growing host culture and a $1.5 \%$ solution of agarose) and we added $2 \mu \mathrm{l}$ of virus on the top of these plates. They were cultured (continuous light $100 \mu \mathrm{mol}$ photon $\mathrm{m}^{-2} \mathrm{~s}^{-1}$, at $20 \pm 1^{\circ} \mathrm{C}$ ) inside a transparent plastic box to maintain humidity for 10 days. Plates that were not lysed 10 days after viral inoculation were considered not to be susceptible to infection by the virus.

Each test was performed in duplicate, to obtain a precise picture of the global pattern of host specificity in prasinoviruses. The specificity of 313 virus strains was tested on 26 host strains.

\section{Molecular data and phylogenetic reconstruction}

Prasinoviruses are typically characterized by analyzing the sequence of a portion of the DNA polymerase gene (or dpo) [13,72]. This marker discriminates for viruses of all of the host genera investigated here, and was used to resolve their phylogenetic status. To amplify viral DNA polymerase fragments from lysis plaques we used a group of specific primers (AVS1-2-5) described previously $[13,72]$. Briefly, PCR reactions were set up as follows: $10 \mu \mathrm{l}$ of virus lysis plaque liquid (with SM buffer) was added to a $90 \mu \mathrm{l}$ reaction mixture which contained PCR assay buffer (Promega), $0.2 \mathrm{mM}$ of each desoxyribonucleoside triphosphate, $1.5 \mathrm{mM} \mathrm{MgCl} 2,30$ pmol of each primer and $0.5 \mathrm{U}$ of Taq DNA polymerase (Promega). PCR bands were purified directly by using a nucleospin kit (Macheray-Nagel company) and DNA fragments were sequenced (Macrogen Inc., Korea or Genomic Core Facility (GENOMER) of the Station Biologique de Roscoff, France). To control for PCR or sequencing errors fragments were sequenced in reverse and forward directions and all nucleotide differences were checked visually.

Algal hosts were characterized via the sequencing of the full 18S rDNA (SSU) and Internal Transcribed Spacer 2
(ITS2). DNA was extracted by a modified cetyltrimethylammonium bromide (CTAB) protocol [73], and cells (200 $\mathrm{ml}$ of a dense culture) were harvested by centrifugation. The pellet was resuspended in $0.8 \mathrm{ml}$ of CTAB buffer, incubated for $30 \mathrm{~min}$ at $60^{\circ} \mathrm{C}$ with $0.1 \mathrm{mg} / \mathrm{ml}$ proteinase $\mathrm{K}$, and DNA was extracted by the addition of $0.8 \mathrm{~mL}$ of chloroform: isoamyl alcohol (24: 1). The sample was then gently agitated for $2 \mathrm{~min}$, and the organic phase was removed after a $10 \mathrm{~min}$ centrifugation step at $4^{\circ} \mathrm{C}$. The aqueous phase was recovered and incubated with $0.6 \mathrm{ml}$ of isopropanol for $30 \mathrm{~min}$ at room temperature to precipitate the DNA. DNA was washed by the addition of $1 \mathrm{ml}$ of $\mathrm{EtOH} \mathrm{76 \% ,} \mathrm{dried,} \mathrm{resuspended} \mathrm{in} \mathrm{sterile} \mathrm{water} \mathrm{and}$ stored at $-20^{\circ} \mathrm{C}$. Extracted DNA was used as a template to amplify the nuclear small subunit ribosomal and ITS2 genes. The eukaryotic primers Euk328f and Euk329r were used to amplify the $18 \mathrm{~S}$ rDNA as described in [74] with the following conditions: an initial incubation step at $95^{\circ} \mathrm{C}$ for $5 \mathrm{~min}$, followed by 34 cycles with a denaturing step at $95^{\circ} \mathrm{C}$ for $1 \mathrm{~min}$, an annealing step at $62^{\circ} \mathrm{C}$ for $2 \mathrm{~min}$ and an extension step at $72^{\circ} \mathrm{C}$ for $3 \mathrm{~min}$. These cycles were followed by a final extension step at $72^{\circ} \mathrm{C}$ for $7 \mathrm{~min}$. The primers D1 (5'-GTA GGT GAA CCT GCG GAA GGA3'), R1 (5'-CCTTGG TCC GTG TTT CTA GAC-3'), D2 (5'-ACC CGC CGA ATT TAA GCA TA-3') and R2 5'AGG GGA ATC CTT GTT AGT TTC-3' were used to amplify the ITS1, 2 and $5.8 \mathrm{~S}$ rDNA, with an initial incubation step at $94^{\circ} \mathrm{C}$ for $12 \mathrm{~min}$, followed by 30 cycles with a denaturing step at $94^{\circ} \mathrm{C}$ for $1 \mathrm{~min}$, an annealing step at $58^{\circ} \mathrm{C}$ for $2 \mathrm{~min}$ and an extension step at $72^{\circ} \mathrm{C}$ for $3 \mathrm{~min}$. These cycles were followed by a final extension step at $72^{\circ} \mathrm{C}$ for $10 \mathrm{~min}$. Polymerase chain reactions were carried out in an automated thermocycler (iCycler, Bio-Rad, Marne-la-Coquette, France). The PCR mixture (25 $\mu \mathrm{l}$ final volume) contained $2.5 \mu \mathrm{l}$ of $\mathrm{Mg}$ Free Buffer 10X (1X final concentration, Promega, Madison, Wisconsin), $2.5 \mu \mathrm{l}$ of $\mathrm{MgCl}_{2}$ solution (2.5 mM final concentration), $2 \mu \mathrm{l}$ of deoxynucleoside triphosphate (dNTP, $400 \mu \mathrm{M}$ final concentration each, Eurogentec), $0.5 \mu \mathrm{l}$ of each primer ( $1 \mu \mathrm{M}$ final contraction each), $0.125 \mu \mathrm{l}$ of Taq Polymerase (5 units per $\mu \mathrm{l}$, Promega, Madison, Wisconsin), sterile water and $1 \mu \mathrm{l}$ of extracted DNA. PCR products were cloned using the TOPO TA cloning kit (Invitrogen, Carlsbad, CA, USA) following the protocol provided by the manufacturer. The $18 \mathrm{~S}$ and ITS2 were concatenated (named here 18S + ITS) after their homogeneity was established using a partition homogeneity test [75].

We combined the results of the host specificity experimental assessment with molecular data to select a non-redundant virus dataset, and we kept the 51 virus strains differing in term of host specificity or dpo nucleotide sequence and the 22 host strains differing in their susceptibility to viruses or with differences in sequences. The full cross-infection dataset (313 virus 
strains on the 26 host strains) is available on request to the authors.

Sequences alignments were performed with MAFFT v5 [76,77], and ambiguously aligned regions were eliminated using GBlocks [78]. Phylogenetic reconstructions were based on DNA and amino acid (AA) sequences (for dpo), using Bayesian inference (BI) and maximum likelihood (ML). Evolutionary models were selected via Akaike Information Criterion using jModelTest v2 [79] for DNA sequences and ProtTest [80] for AA sequences. Bayesian analysis were carried out done with MrBayes 3.1.2 [81], with 4 chains of $10^{6}$ generations, trees sampled every 100 generations, and burnin value set to $20 \%$ of the sampled trees. In BI, coding DNA sequences (dpo) were considered with an evolutionary model designed for coding sequences taking the genetic code into account [82-84], and AA sequences were analyzed with a mixed model [81]. We checked that standard deviation of the split frequencies fell below 0.01 to ensure convergence in tree search. Maximum likelihood reconstructions were carried out using PhyML $[85,86]$ and validated with 1000 bootstrap replicates.

No outgroups were used: trees were oriented using previous knowledge from [14] for hosts (where Micromonas is the basal lineage) and [11] for viruses (with $\mathrm{BpV}$ as the basal lineage).

\section{Cophylogeny}

Several methods have been published to study cophylogenetic patterns between hosts and their symbionts [9,41], which can be classified into event-based methods and global fit methods [10]. Event-based methods aim at reconciling tree topologies of hosts and symbionts by adequately mixing generally four (sometimes more) kinds of coevolutionary events (cospeciation or codivergence, host-switch, duplication, sorting) and find the best reconstructions by minimizing its global cost (each event type is attributed a cost). A cophylogenetic scenario is produced, but the computational cost is very heavy (and the number of optimal scenarios can be very high), especially when exhaustive algorithms are used. The significance of the global cost is assessed against a random distribution of costs generated using random trees - if the observed optimal cost is significantly lower than optimal costs computed from randomly generated trees, then a global cospeciation signal is present. Global fit methods do not rely on events but assess the congruence between the two trees taking the pattern of host specificity into account encoded via a presence-absence matrix; again the observed level of congruence is tested against a random distribution. No scenario is produced but the computational burden is much lighter than for eventbased methods, and a result can be obtained with any kind of associations, even with large trees and complex patterns of host specificity. We used an event-based method, Jane v4 [45] and a global fit method, ParaFit [43], implemented in CopyCat [87]. Jane was chosen (instead of the popular TreeMap [42], TreeMap 3 is currently being developed by Mike Charleston and is available at http://sites.google.com/site/cophylogeny, and was used here to draw the tanglegram on Figure 1) because it uses a heuristic algorithm that can be used even with complex host-symbiont systems such as this one. Jane considers a fifth type of coevolutionary event, "Failure to diverge", accounting for situation where, following a host speciation event, the symbiont remains on each new host species without speciating. Jane $\mathrm{v} 4$ can also handle polytomies (while TreeMap cannot). In Jane, polytomies are considered as soft polytomies, and the algorithm resolves polytomies in both trees in order to minimize the total cost of the reconstruction. The option "Prevent mid-polytomy" was selected to ensure the absence of duplication or host-switch involving the branch created to resolve the polytomy. In addition to assessing and testing the global congruence between trees, ParaFit can assess the contribution of each individual host-parasite association ("links") to this global congruence. This allows one to identify which host-parasite couples are the most structuring in the association. Jane was used with the following event-cost scheme (Cospeciation $=0$, Duplication $=1$, Host switch $=2$, Sorting $=1$, Failure to diverge $=1$ ), a number of generations of 500 and a population size of 50. This cost scheme was used because we considered, as in several other studies, that cospeciation is the default situation, so its cost was set to 0 (e.g. $[38,50,88])$. Host-switching was considered as the least probable event and was assigned of cost of 2 . For a good discussion on event costs, see [88]. Note that several cost schemes were assessed, and comparable results were obtained. Statistical tests for tree congruence in ParaFit and Jane were carried out with 999 permutations, and parasite trees instead of tip mappings were randomized in Jane.

\section{Availability of supporting data}

GenBank accession numbers for the sequences used in this study are provided in Tables 2 and 3.

Sequences newly submitted for this study have GenBank accession numbers KF500985 to KF501037.

\section{Competing interests}

The authors declare that they have no competing interests.

\section{Authors' contributions}

$L B, C C, R E, E F$ and NS carried out the molecular biology and virology experiments. YD and LB performed the data analyses. YD, LB, NS and NG wrote the manuscript. All the authors read, edited and approved the final manuscript.

\section{Acknowledgments}

We thank the captain and crew of the Nereis II for collection of water from Banyuls' Bay (SOLA), as well as the captain and crew of the Neomysis for collecting water from the SOMLIT-Astan monitoring station off Roscoff. We also thank Fabienne Rigaut-Jalabert for helping with the natural samples 
processing and Julie Bergeret for helping with viral strains isolation and characterization. Our strains are deposited for distribution in the Roscoff Culture Collection (http://www.sb-roscoff.fr/Phyto/RCC/). We thank the GENOMER of the Station Biologique de Roscoff, France, for advices on the sequencing procedure. The work was supported by the French National Agency grant PICOVIR ANR-07-BLAN-0210 (coordinator N.G.). Laure Bellec benefited from a doctoral fellowship from the French Ministry of Education and Research. This research does not involve human subjects, human material, or human data, nor animals or plant subjected to any ethical framework, thus no ethic approval was needed.

\section{Author details}

'Integrative Biology of Marine Organisms, Observatoire Océanologique, Sorbonne Universités, UPMC Univ Paris 06, UMR 7232, F-66650 Banyuls-sur-Mer, France. ${ }^{2}$ Integrative Biology of Marine Organisms, Observatoire Océanologique, CNRS, UMR 7232, 66650 Banyuls-sur-Mer, France. ${ }^{3}$ Marine Adaptation and Diversity, Station Biologique de Roscoff, Sorbonne Universités, Univ Paris 06, UMR 7144, F-29680 Roscoff, France. ${ }^{4}$ Marine Adaptation and Diversity, Station Biologique de Roscoff, CNRS, UMR 7144, 29680 Roscoff, France.

Received: 8 January 2014 Accepted: 20 March 2014 Published: 27 March 2014

\section{References}

1. Suttle C: Marine viruses - major players in the global ecosystem. Nat Rev Microbiol 2007, 5(10):801-812.

2. Weinbauer M: Ecology of prokaryotic viruses. FEMS Microbiol Rev 2004 28(2):127-181.

3. Brussaard C: Viral control of phytoplankton populations - a review J Eukyot Microbiol 2004, 51(2):125-138.

4. Short SM: The ecology of viruses that infect eukaryotic algae. Environ Microbiol 2012, 14(9):2253-2271.

5. Rohwer $F$, Thurber R: Viruses manipulate the marine environment. Nature 2009 , 459(7244):207-212.

6. Nagasaki K, Tomaru Y, Tarutani K, Katanozaka N, Yamanaka S, Tanabe H, Yamaguchi M: Growth characteristics and intraspecies host specificity of a large virus infecting the dinoflagellate Heterocapsa circularisquama. Appl Environ Microbiol 2003, 69(5):2580-2586.

7. Derelle E, Ferraz C, Escande M-L, Eychenié S, Cooke R, Piganeau G, Desdevises $Y$, Bellec L, Moreau H, Grimsley N: Life-cycle and genome of OtV5, a large DNA virus of the pelagic marine unicellular green alga Ostreococcus tauri. PLOS ONE 2008, 3(5):e2250.

8. Clerissi C, Desdevises Y, Grimsley N: Prasinoviruses of the marine green alga Ostreococcus tauri are mainly species specific. J Virol 2012, 86(8):4611-4619.

9. Page RDM: Tangled Trees: Phylogeny, Cospeciation, and Coevolution. Chicago: The University of Chicago Press; 2003

10. Desdevises Y: Cophylogeny: insights from fish-parasite systems. Parassitologia 2007, 49(3):125-128

11. Moreau H, Piganeau G, Desdevises Y, Cooke R, Derelle E, Grimsley N: Marine prasinovirus genomes show low evolutionary divergence and acquisition of protein metabolism genes by horizontal gene transfer. J Virol 2010, 84(24):12555-12563.

12. Dunigan D, Fitzgerald L, Van Etten J: Phycodnaviruses: a peek at genetic diversity. Virus Res 2006, 117(1):119-132.

13. Bellec L, Grimsley N, Moreau H, Desdevises Y: Phylogenetic analysis of new Prasinoviruses (Phycodnaviridae) that infect the green unicellular algae Ostreococcus, Bathycoccus and Micromonas. Environ Microbiol Rep 2009, 1(2):114-123.

14. Marin B, Melkonian M: Molecular phylogeny and classification of the Mamiellophyceae class. nov. (Chlorophyta) based on sequence comparisons of the nuclear- and plastid-encoded rRNA operons. Protist 2010, 161(2):304-336.

15. Vaulot D, Eikrem W, Viprey M, Moreau H: The diversity of small eukaryotic phytoplankton ( $\leq 3 \mu \mathrm{m})$ in marine ecosystems. FEMS Microbiol Rev 2008, 32(5):795-820.

16. Guillou L, Eikrem W, Chrétiennot-Dinet M, Le Gall F, Massana R, Romari K, Pedrós-Alió C, Vaulot D: Diversity of picoplanktonic prasinophytes assessed by direct nuclear SSU rDNA sequencing of environmental samples and novel isolates retrieved from oceanic and coastal marine ecosystems. Protist 2004, 155(2):193-214.
17. Rodriguez F, Derelle E, Guillou L, Le Gall F, Vaulot D, Moreau H: Ecotype diversity in the marine picoeukaryote Ostreococcus (Chlorophyta, Prasinophyceae). Environ Microbio/ 2005, 7(6):853-859.

18. Grimsley N, Péquin B, Bachy C, Moreau H, Piganeau G: Cryptic sex in the smallest eukaryotic marine green alga. Mol Biol Evol 2010, 27(1):47-54.

19. Courties C, Vaquer A, Troussellier M, Lautier J, Chretiennot-Dinet M, Neveux J, Machado C, Claustre H: Smallest eukaryotic organism. Nature 1994, 370(6487):255.

20. Palenik B, Grimwood J, Aerts A, Rouzé P, Salamov A, Putnam N, Dupont C, Jorgensen R, Derelle E, Rombauts S, Zhou K, Otillar R, Merchant S, Podell S, Gaasterland T, Napoli C, Gendler K, Manuell A, Tai V, Vallon O, Piganeau G, Jancek S, Heijde M, Jabbari K, Bowler C, Lohr M, Robbens S, Werner G, Dubchak I, Pazour GJ, et al: The tiny eukaryote Ostreococcus provides genomic insights into the paradox of plankton speciation. Proc Natl Acad Sci USA 2007, 104(18):7705-7710.

21. Subirana L, Péquin B, Michely S, Escande ML, Meilland J, Derelle E, Piganeau G, Desdevises Y, Moreau H, Grimsley N: Morphology, genome plasticity, and phylogeny in the genus Ostreococcus reveal a cryptic species $O$. mediterraneus (sp. nov., Mamiellales, Mamiellophyceae). Protist 2013, 164:643-659.

22. Slapeta J, Lopez-Garcia P, Moreira D: Global dispersal and ancient cryptic species in the smallest marine eukaryotes. Mol Biol Evol 2006, 23(1):23-29.

23. Worden AZA, Cuvelier MLM, Bartlett DHD: In-depth analyses of marine microbial community genomics. Trends Microbiol 2006, 14(8):331-336.

24. Lovejoy C, Vincent W-F, Bonilla S, Roy S, Martineau M-J, Terrado R, Potvin M, Massana R, Pedrós-Alió C: Distribution, phylogeny, and growth of coldadapted picoprasinophytes in arctic seas. J Phycol 2007, 43(1):78-89.

25. Demir-Hilton E, Sudek S, Cuvelier ML, Gentemann CL, Zehr JP, Worden AZ: Global distribution patterns of distinct clades of the photosynthetic picoeukaryote Ostreococcus. ISME J 2011, 5(7):1095-1107.

26. Vaulot D, Lepère C, Toulza E, De la Iglesia R, Poulain J, Gaboyer F, Moreau H, Vanderpoele K, Ulloa O, Gavory F, Piganeau G: Metagenomes of the picoalga Bathycoccus from the Chile coastal upwelling. PLOS ONE 2012, 7:e39648.

27. Bellec L, Grimsley N, Desdevises Y: Isolation of Prasinoviruses of the Green Unicellular Algae Ostreococcus spp. on a Worldwide Geographical Scale. Appl Environ Microbiol 2010, 76(1):96-101.

28. Manton I, Parke M: Further observations on a small green flagellate with special reference to possible relatives of Chromulina pusilla Butcher. J Mar Biol Ass UK 1960, 39:275-298.

29. Moreau H, Verhelst B, Couloux A, Derelle E, Rombauts S, Grimsley N, Van Bel M, Poulain J, Katinka M, Hohmann-Marriott MF, Piganeau G, Rouzé P, Da Silva C, Wincker P, Van de Peer Y, Vandepoele K: Gene functionalities and genome structure in Bathycoccus prasinos reflect cellular specializations at the base of the green lineage. Genet Biol 2012, 13(8):R74.

30. Thomas R, Grimsley N, Escande M-L, Subirana L, Derelle E, Moreau H: Acquisition and maintenance of resistance to viruses in eukaryotic phytoplankton populations. Environ Microbio/ 2011, 13(6):1412-1420.

31. Sahlsten E: Seasonal abundance in Skagerrak-Kattegat coastal waters and host specificity of viruses infecting the marine photosynthetic flagellate Micromonas pusilla. Aquat Microb Ecol 1998, 16(2):103-108.

32. Sahlsten E, Karlson B: Vertical distribution of virus-like particles (VLP) and viruses infecting Micromonas pusilla during late summer in the southeastern Skagerrak, North Atlantic. J Plankton Res 1998, 20(11):2207-2212.

33. Van Etten JL, Dunigan DD: Chloroviruses: not your everyday plant virus. Trends Plant Sci 2012, 17(1):1-8.

34. Marie D, Zhu F, Balague V, Ras J, Vaulot D: Eukaryotic picoplankton communities of the Mediterranean Sea in summer assessed by molecular approaches (DGGE, TTGE, QPCR). FEMS Microbiol Ecol 2006, 55(3):403-415.

35. Foulon $E$, Not F, Jalabert F, Cariou T, Massana R, Simon N: Ecological niche partitioning in the picoplanktonic green alga Micromonas pusilla: evidence from environmental surveys using phylogenetic probes. Environ Microbio/ 2008, 10(9):2433-2443.

36. Brooks DR: Testing the context and extent of host-parasite coevolution. Syst Zool 1979, 28:299-307

37. Hafner MS, Sudman PD, Villablanca FX, Spradling TA, Demastes JW, Nadler S. Disparate rates of molecular evolution in cospeciating hosts and parasites. Science 1994, 265:1087-1090.

38. Ricklefs $\mathrm{R}$, Fallon $\mathrm{S}$, Bermingham E: Evolutionary relationships, cospeciation, and host switching in avian Malaria parasites. Syst Biol 2004, 53(1):111-119.

39. Huyse T, Volckaert F: Comparing host and parasite phylogenies: Gyrodactylus flatworms jumping from goby to goby. Syst Biol 2005, 54(5):710-718. 
40. Light J, Hafner M: Codivergence in heteromyid rodents (Rodentia: Heteromyidae) and their sucking lice of the genus Fahrenholzia (Phthiraptera: Anoplura). Syst Biol 2008, 57(3):449-465.

41. Brooks DR: Hennig's parasitological method: a proposed solution. Syst Zool 1981, 1981(30):229-249.

42. Page RDM: Parallel phylogenies: reconstructing the history of host-parasite assemblages. Cladistics 1994, 10(2):155-173.

43. Legendre P, Desdevises Y, Bazin E: A statistical test for host-parasite coevolution. Syst Biol 2002, 51(2):217-234.

44. Hommola K, Smith J, Qiu Y, Gilks W: A permutation test of host-parasite cospeciation. Mol Biol Evol 2009, 26(7):1457-1468.

45. Conow C, Fielder D, Ovadia Y, Libeskind-Hadas R: Jane: a new tool for the cophylogeny reconstruction problem. Alg Mol Biol 2010, 5:16.

46. Merkle $D$, Middendorf $M$, Wieseke $N$ : A parameter-adaptive dynamic programming approach for inferring cophylogenies. BMC Bioinforma 2010, 11(Suppl 1):S60.

47. Bowen M, Peters C, Nichol S: Phylogenetic analysis of the Arenaviridae: patterns of virus evolution and evidence for cospeciation between Arenaviruses and their rodent hosts. Mol Phyl Evol 1997, 8(3):301-316.

48. Jackson A, Charleston M: A cophylogenetic perspective of RNA-virus evolution. Mol Biol Evol 2004, 21(1):45-57.

49. Lewis-Rogers N, Crandall K: Evolution of Picornaviridae: an examination of phylogenetic relationships and cophylogeny. Mol Phyl Evol 2010, 54:995-1005.

50. Gottschling M, Göker M, Stamatakis A, Bininda-Emonds O, Nindl I, Bravo I: Quantifying the phylodynamic forces driving papillomavirus evolution. Mol Biol Evol 2011, 28(7):2101-2113.

51. Morgan A, Buckling AD: Relative number of generations of hosts and parasites does not influence parasite local adaptation in coevolving populations of bacteria and phages. J Evol Biol 2006, 19(6):1956-1963.

52. Charrel R, De Micco P, de Lamballerie X: Phylogenetic analysis of GB viruses $A$ and $C$ : evidence for cospeciation between virus isolates and their primate hosts. J Gen Virol 1999, 80(9):2329-2335.

53. Dimcheff D, Drovetski S, Krishnan M, Mindell D: Cospeciation and horizontal transmission of avian sarcoma and leukosis virus gag genes in galliform birds. J Virol 2000, 74(9):3984-3995.

54. Mang R, Maas J, van der Kuyl A, Goudsmit J: Papio cynocephalus endogenous retrovirus among Old World monkeys: Evidence for coevolution and ancient cross-species transmissions. J Virol 2000, 74(3):1578-1586.

55. Hugot J-P, Gonzalez J, Denys C: Evolution of the Old World Arenaviridae and their rodent hosts: generalized host-transfer or association by descent? Infect Gen Evol 2001, 1(1):13-20.

56. Charleston M, Robertson D: Preferential host switching by primate lentiviruses can account for phylogenetic similarity with the primate phylogeny. Syst Biol 2002, 51(3):528-535.

57. Whitfield J, Asgari S: Virus or not? Phylogenetics of polydnaviruses and their wasp carriers. J Ins Physiol 2003, 49(5):397-405.

58. Switzer W, Salemi M, Shanmugam V, Gao F, Cong M, Kuiken M, Bhullar CV, Beer BE, Vallet D, Gautier-Hion A, Tooze Z, Villinger F, Holmes EC, Heneine W: Ancient co-speciation of simian foamy viruses and primates. Nature 2005, 434(7031):376-380

59. Pérez-Losada M, Christensen RG, McClellan DA, Adams BJ, Viscidi RP, Demma JC, Crandall KA: Comparing phylogenetic codivergence between polyomaviruses and their hosts. J Virol 2006, 80(12):5663-5669.

60. Pal C, Maciá M, Oliver A, Schachar I, Buckling A: Coevolution with viruses drives the evolution of bacterial mutation rates. Nature 2007, 450(7172):1079-1081.

61. Wu B, Melcher U, Guo X, Wang X, Longjiang F, Guanghe Z: Assessment of codivergence of Mastreviruses with their plant hosts. BMC Evol Biol 2008 , 8:335.

62. Ehlers B, Dural G, Yasmum N, Lembo T, De Thoisy B, Ryser-Degiorgis M-P, Ulrich RG, McGeoch DJ: Novel mammalian Herpesviruses and lineages within the Gammaherpesvirinae: cospeciation and interspecies transfer. $J$ Virol 2008, 82(7):3509-3516.

63. Shah S, Doorbar J, Goldstein RA: Analysis of host-parasite incongruence in papillomavirus evolution using importance sampling. Mol Biol Evol 2010, 27(6):1301-1314.

64. Muniz CP, Troncoso LL, Moreira MA, Soares EA, Pissinatti A, Bonvicino CR, Seuanez HM, Sharma B, Jia H, Shankar A, Switzer WM, Santos AF, Soares MA: Identification and characterization of highly divergent simian foamy viruses in a wide range of New World primates from Brazil. PLOS ONE 2013, 8(7):e67568.
65. Ramsden C, Holmes E, Charleston M: Hantavirus evolution in relation to its rodent and insectivore hosts: no evidence for codivergence. Mol Biol Evol 2009, 26(1):143-153.

66. Nemirov K, Leirs H, Lundkvist A: Puumala hantavirus and Myodes glareolus in northern Europe: no evidence of co-divergence between genetic lineages of virus and host. J Gen Virol 2010, 91(5):1262-1274.

67. De Vienne DM, Giraud T, Shykoff JA: When can host shifts produce congruent host and parasite phylogenies? A simulation approach. J Evol Biol 2007, 20(4):1428-1438.

68. De Vienne DM, Refrégier G, López-Villavicencio M, Tellier A, Hood ME, Giraud T: Cospeciation vs host-shift speciation: methods for testing, evidence from natural associations and relation to coevolution. New Phytol 2013, 198(2):347-385.

69. Firth C, Kitchen A, Shapiro B, Suchard MA, Holmes EC, Rambaut A: Using time-structured data to estimate evolutionary rates of double-stranded DNA viruses. Mol Biol Evol 2010, 27(9):2038-2051.

70. Page RDM, Hafner MS: Molecular Phylogenies of Host-Parasite Cospeciation: Gophers and Lice as a Model System. In New Uses for new Phylogenies. Edited by Harvey PH, Brown AJL, Maynard Smith J, Nee S. Oxford: Oxford University Press; 1996.

71. Guillard RRL, Hargraves PE: Stichochrysis immobilis is a diatom, not a chrysophyte. Phycologia 1993, 32:234-236.

72. Chen F, Suttle C: Amplification of DNA polymerase gene fragments from viruses infecting microalgae. Appl Env Microbiol 1995, 61(4):1274-1278.

73. Winnepenninckx B, Backeljau T, De Wachter R: Extraction of high molecular weight DNA from molluscs. Trends Genet 1993, 9(12):407.

74. Romari K, Vaulot D: Composition and temporal variability of picoeukaryote communities at a coastal site of the English Channel from 18S rDNA sequences. Limnol Oceanogr 2004, 49:784-798.

75. Farris JS, Kallersjo M, Kluge AG, Bult C: Testing significance of incongruence. Cladistics 1994, 10:315-319.

76. Katoh K, Misawa K, Kuma K, Miyata T: MAFFT: a novel method for rapid multiple sequence alignment based on fast Fourier transform. Nucleic Acid Res 2002, 30:3059-3066.

77. Katoh K, Kuma K, Toh H, Miyata T: MAFFT version 5: improvement in accuracy of multiple sequence alignment. Nucleic Acid Res 2005, 33:511-518.

78. Castresana J: Selection of conserved blocks from multiple alignments for their use in phylogenetic analysis. Mol Biol Evol 2000, 17(4):540-552.

79. Darriba D, Taboada GL, Doallo R, Posada D: jModelTest 2: more models, new heuristics and parallel computing. Nature Methods 2012, 9:772.

80. Abascal F, Zardoya R, Posada D: ProtTest: selection of best-fit models of protein evolution. Bioinformatics 2005, 21:2104-2105.

81. Ronquist F, Huelsenbeck JP: MRBAYES 3: Bayesian phylogenetic inference under mixed models. Bioinformatics 2003, 19:1572-1574.

82. Goldman N, Yang ZH: Codon-based model of nucleotide substitution for protein-coding DNA-sequences. Mol Biol Evol 1994, 11(5):725-736.

83. Muse SV, Gaut BS: A likelihood approach for comparing synonymous and nonsynonymous nucleotide substitution rates, with application to the chloroplast genome. Mol Biol Evol 1994, 11(5):715-724.

84. Shapiro B: Choosing appropriate substitution models for the phylogenetic analysis of protein-coding sequences. Mol Biol Evol 2005, 23(1):7-9.

85. Guindon S, Gascuel O: A simple, fast and accurate method to estimate large phylogenies by maximum-likelihood. Syst Biol 2003, 52(5):696-704.

86. Guindon S, Lethiec F, Duroux P, Gascuel O: PHYML Online: a web server for fast maximum likelihood-based phylogenetic inference. Nucleic Acid Res 2005, 33:557-559.

87. Meier-Kolthoff J, Auch A, Huson D, Goker M: COPYCAT: cophylogenetic analysis tool. Bioinformatics 2007, 23(7):898-900.

88. Ronquist F: Phylogenetic approaches in coevolution and biogeography. Zool Scr 1997, 26(4):313-322.

doi:10.1186/1471-2148-14-59

Cite this article as: Bellec et al:: Cophylogenetic interactions between marine viruses and eukaryotic picophytoplankton. BMC Evolutionary Biology 2014 14:59. 